\title{
STRUCTURAL ANALYSIS IN RICHARD WRIGHT'S NATIVE SON
}

\author{
By. IKE ANISA \\ SUHUD EKO YUWONO \\ ikeanisa@yahoo.com / ikeanisa@unwidha.ac.id
}

UNIVERSITAS WIDYA DHARMA KLATEN

\begin{abstract}
A novel is proved of the real condition of the person. Sometimes it reflects the background from the author of the novel. By the novel, an author can express the idea or feeling that derives from his life. In short, the story in a novel can be portrait of the real condition in a certain time.

Here, Richard Wright as the author of the Native Son expressed his idea and his feeling through the writing of the novel. His novel full the message that could be represented his real life condition.

This study tries to explore the structural analysis of the character, setting, plot, point of view and style. Here, the writer tries to analyze the characters including the characterization of the major character and the minor character, setting of time and place, plot of the story, point of view, style and theme. This analysis of the structural elements of Native Son is meant to reveal the internal coherence that explains the author's worldview.
\end{abstract}

Keywords: Richard Wright, Native Son

\section{INTRODUCTION}

Richard Wright was born as Richard Nathaniel Wright in nrst Natchez, Mississippi. He is the son of Nathan Wright, an illiterate sharecropper, and Ella Wilson, a schoolteacher (www.math,buffalo.edu/ sww/wright/wright_bio.html). When he was five years old, his father left him with his mother and brother. Wright was grown with one of his family in Mississippi. In 1925 Wright moved to Memphis and after that he moved to the other place for twenty times. Poverty made him unable to study further; he only studied in the junior high school. Religious background given from his grandmother affected his life.

In 1937 Richard Wright went to New York City, where e became Harlem editor of the Communist paper, Daily Worker. In 1938, Wright published Uncle Tom's Children, 
Bright and Morning Star appears in New Masses, and Wright soon joins that magazine's editorial board (www.math,buffalo.edu/ sww/wright/wright_bio.html). He worked on new novel and collect clippings from the Robert Nixon case in Chicago. In October, he finishes the first draft of the novel which he calls Native Son. Native Son was published in 1940, makes Wright as a first famous black writer. Then he continued to write his autobiography with the title Black Boy (1945).

In 1946 Wright visited France then he stayed there. He regarded as a modern prose writer and his place equal with Hemingway, Fitzgerald and Faulkner. One of the existential novels, The Outsider, is published in 1953. And Eight Men is the last literary work that he finished and published after his death.

Native Son was the best work of Richard Wright, which appeared in 1940. The book immediately, established Wright as an important author and a spokesperson on conditions facing African-Americans. Wright's powerful novel reflects the forces of poverty, injustice, and hopelessness that continue to shape our society. And this condition is reflected on his Native Son through the characters on it.

In this research, the writer will analyze Richard Wright's novel entitled Native Son. The researcher is interested in analyzing the structural analysis of the novel entitled Native Son. The learning of this novel is meant to comprehend deeply the fact and reality at that time. The message of the author is carried out through the intrinsic elements $f$ the novel.

\section{OBJECTIVE OF THE STUDY}

The objective of the study is to analyze the novel in terms of its structural elements.

\section{RESEARCH METHOD}

In analyzing Richard Wright's Native Son, the writer uses qualitative method. Dealing with research method, there will be at least four points that need to be involved as follows:

\section{1 . Object of the Study}

The object of the study is Richard Wright's Native Son.

\section{Data Sources}


In doing the study, the writer uses two sources of data, namely:

a. Primary data source

The primary data source is the novel of Native Son itself by Richard Wright

b. Secondary data sources

The secondary data sources are some material related o the data requires, such as the writer's biography, related theories, etc.

\section{Method of Data Collection}

The method of data collection in this study is library research. The writer collects and records the data from both primary and secondary data analysis.

\section{Technique of Data Analysis}

In this study the technique that is used to analyze the data is content analysis through structural elements of the novel.

\section{STRUCTURAL ELEMENTS OF THE LITERARY WORK}

\section{Character and characterization}

Character and characterization are the essential elements of the narrative literary work. Character means "the actor". According to Abrams (in Nurgiyantoro, 2000: 165) character is people who show up in narrative literary work that has moral quality and certain tendency which are expressed in conversation and act.

There are two kinds of characters, major and minor characters. Major character dominates most of art of the story, while the existence of minor character is as supporting character.

Characterization is the description of character in the story or literary work it includes physical mental, social and moral elements of character.

\section{Setting}

Setting refers o the term of place, time correlation and social environment when and where the story took place (Abrams in Nurgiyantoro, 2000: 216). The social environment here influenced to the character of the story. There are two kinds of setting, setting of place and setting of time. 


\section{Plot}

Plot refers to the arrangement of happenings or event in the story. Plot is reflection or even the journey of the character acting, thinking, feeling and getting attitude to face the problem of life (Nurgiyantoro, 2000: 114).

According to Barnet (1963: 13) the story could be understand by showing exposition, conflict, and climax the ends with resolution to show the chronology of the story.

a. Exposition

It is the basic function on the beginning of the story which leads to the further development of a story (Barnet: 1963). The author introduces the characters setting and historical background.

b. Complication

It is series of event of casual relationship which lead to the rising of conflict (Barnet, 963: 14). The problem made more difficult to solve.

c. Climax

It is the most intense event in fictions, which is reached when the rising actions on the highest points of intensity (Barnet, 1963: 14) .

d. Resolution

It is the stable situation as the end of fiction. It makes the story as tragedy or comedy (Barnet, 1963: 14).

\section{Point of view}

Point of view is emphasized on how the stories tell. It's a way that used by the writer to show how's the character, act, background, and events construct the literary works and could easily understand by the readers (Abrams in Nurgiyntoro, 2000: 142). In other words the point of view is a strategy, technique, that used by the writer to express their ideas and their stories literary works.

\section{Style}

Style according to Kenney (1966: 102) is the construction of words arranged by the author to interest the reader. Also it is a characteristic of the author background which is presented is a story. Abrams (in Nurgiyantoro, 2000: 289-310) points out that 
there are many things involved in style, for example, diction, grammatical structure, and rhetorical.

a. Diction

It refers to the authors' choice of words. An author when choosing the words to his work will choose the words that are appropriate with his idea in order to get a certain effect and established (Nurgiyantoro, 2000: 290).

b. Grammatical structure

It means the suggestion of the sentence structure in creating the sentence; the author is free in using the language. He can use the deviation of the sentence structure. It can be in the repetition, abbreviation, or desperation in order to get the esthetic effect.

c. Rhetoric

Rhetoric is the manner of using the language to get the esthetic. It refers to the author's way to express the language in order to make the reader know his idea (Nurgiyantoro, 2000: 295). Abrams (in Nurgiyantoro: 2000: 295) argues that rhetoric consists of figurative language and imagery.

1) Figurative language

The figurative language can be divided into two parts: figures of thought and figures of speech (Nurgiyantoro, 2000: 296).

(a) Figures of thought

The trick of language that is close to the literal meaning uses an author called figures of thought. There are five prominent figures of thought: simile, metaphor, personification, hyperbole, and paradox (Nurgiyantoro, 2000: 296-300). First, simile is used for direct comparison and eplicit with used a certain task word and an explicit as a mark such as: like, as, as if, resemble, and others. Second, metaphor is the figurative of phrases to describe something of two different classes in order to show the same qualities and to make it more forceful. Third, personification is a figurative language which provides the nature of fixed object with the nature of man properly, until it can behave like man, fourth, hyperbole is a language style which emphasize meaning which full of exaggerate and the last, paradox is language style which emphasizes phrases; expressing forward and stressing elements inside. 
(b) Figures of speech

The effectiveness of literary work is influenced by the whole of the sentence structure. Sometimes, there are some conspicuous sentence structure in literary work that can give the other impression. Figures of speech talk about this conspicuous sentence structure. It can be a deviation or the others. This conspicuous sentence structure is written by author in order to get the esthetic function (Nurgiyantoro, 2000: $300-$ $301)$.

There are some figures of speech, but some of them use the repetition style. It can be repetition of words, phrases and sentence. the other forms are repetition, parallelism, anaphora, polysindenton, asyndenton, antithesis, litrasi, and rhetoric questions (Nurgiyantoro, 2000: $300-301)$.

First, repetition is word of group of word repetition. It can be in one sentence or more, in the beginning, middle, or the other places of sentence. Second, anaphora, a repetition can be called an anaphora if there are at least two consecutively sentence that used word or group of word repetition in the beginning of sentence. Third, polysindenton is a repetition that used the word 'and' repetition, and the last, asyndenton is a repetition that uses comme (,) punctuation repetition.

2) Imagery

Imagery is the use of words and sentence expressed by the author. It has a function to make the readers imagine, fell and concrete a condition in the story that actually abstract (Nurgiyantoro, 2000: 304).

\section{Theme}

Theme of a story is considered as the actual thought or idea of the author to overcome the social problem he faces. Kennedy states that theme of a story as whatever general idea or insight the entire story reveals. A theme need not to be a moral or a message, it may be what the happenings add up to, what the story is about (Kennedy, 1983: 103). 


\section{DISCUSSION}

The discussion of the structural elements of this novel consists of; character and characterization, setting, plot, point of view, style, and theme. This analysis of structural elements of Native Son is meant to reveal the internal coherence that explains the author's worldview.

\section{A. Structural Elements}

\section{Character and Characterization}

\section{a. Major Character}

(1) Bigger Thomas

As the main character of Native Son, Bigger is the focus of the novel and the embodiment of its main theme. He is a black boy who lives in poverty.

Light flooded the room and revealed a black boy standing in a narrow space between two iron beds, rubbing his eyes with the backs of his hands (Wright, 1989: 7) .

Bigger grows to be an independent boy, who is impatience with his family's poverty.

He hated his family because he knew that they were suffering and that he was powerless to help them. He knew that the moment he allowed himself to feel to its fullness how they lived, the shame and misery of their lives, he would be swept out of himself with fear and despair. (Wright, 1989: 13).

Bigger is an emotional man, it shows when he caught the rat and killed it.

He kicked the splintered box out of the way and the fat black body of the rat lay exposed, its two long yellow tusks showing distinctly. Bigger took shoe and pounded the rat's head, crushing it, crushing hysterically:

"You sonofabitch!" (Wright, 1989: 10). 
However, Bigger still has heart and patient. In the end of the story, Bigger feels that he needs friendship and he does not look like a killer. It is shown when Bigger asks Max to send his message for his family and also for Jan.

"I'm all right, Mr. Max, Just go and tell Ma that I was all right and not to worry none, see? Tell her I was all right and wasn't crying none..."

'Max walked down the corridor.

"Mr. Max!"

Max Paused, but did not look.

"Tell... Tell Mister ... Tell Jan hello ..."

“All right Bigger." (Wright, 1989: 392)

(2) Mary Dalton

She is the daughter of Mr. and Mrs. Dalton, white girl and Bigger looks that she is a weird girl. "Bigger turned and saw a white girl walk into the room. She was very slender" (Wright, 1989: 53), "She was an odd girl, all right" (Wright, 1989 : 66).

Mary identifies herself as progressive, dates and admitted communist, and interacts with Bigger with little regard for the strict boundary society imposes between black men and white women.

"Is this the new chauffeur?"

"Yes" said Mr. Dalton, "This is Bigger Thomas."

"Hello, Bigger," the girl said.

The girl came close to him and stopped just opposite his chair.

"Bigger, do you belong to a union?" she asked (Wright, 1989: 53).

Mary makes the relationship with Bigger by making him as her friend, and introducing Bigger to her love, Jan.

"Oh, Bigger, this is Jan. and Jan, this is Bigger Thomas."

Jan smiled broadly, then extended an open palm toward him.

"How are you, Bigger?"

Biggers' right hand still gripped the steering wheel and wondered if he ought to shake hands with this white man,

"Im fine," he mumbled (Wright, 1989: 66)

And she also asks Bigger to take a sit near of them when they want to get meal in the colored people eat in usual place. 
“Aren't you hungry?" Jan asked.

"Naw; I ain't hungry."

Jan and Mary came close to the car.

"Come and sit with us anyhow." Jan said.

"I...I,,,: Bigger stammered.

"It'll be all right," Mary said

"I can stay here. Somebody has to watch the car," he said.

"O, to hell with the car!" Mary said. "Come on in".

"I don't want to eat," Bigger said stubbornly.

"Well," Jan sighed. "If that's the way you feel about it, we won't go in." (Wright, 1989: 71).

(3) Boris A. Max

He is the lawyer who defends Bigger at his trial. Max is a membet of the Labor Defenders, a legal organization affiliated with the communist party, "I want to talk to you," Max said. "I'm from the Labor Defenders. I want to help you" (Wright, 1989: 270).

He is a white man and tall.

Jan went to the door. A policeman opened it from the outside. Bigger sat, open-mouthed, trying to feel where all this was bearing him. He saw a man's head come into the door, a head strange and white, with silver and a lean white face that had never seen before.

"Come on in," Jan said.

"Thanks."

The voice was quiet, firm, but kind; there was about the man's thin lops a faint smile that seemed to have always been there. The man stepped inside; he was tall. (Wright, 1989: 269).

Of all the white characters in the novel, Max is able to see and understand Bigger most clearly. He speaks to Bigger s a human being rather than simply as a black man or murdered, which gives Bigger the chance to tell his own story. Max tries to make a close distance between himself and Bigger. It can be clearly see when Max is talking with Bigger about his problem.

"Are you willing to let us handle your case?"

"I ain't got no money."

"Forget about that. Listen, they're taking you back to the inquest this afternoon. But you don't have to answer any questions, see? Just sit and say nothing. I'll be there and you won't have to be scared. After the inquest they'll take you to the Cook County Jail and I'll be over to talk to you."

"Yessuh." 
"Here; take these cigarettes."

“Thank you, suh.” (Wright, 1989: 270)

The dialogue shows that Max, as a white man, really wants to help igger Thomas.

\section{b. Minor character}

(1) Jan Erlone

$\mathrm{He}$ is a white man who is also a member of the Communist Party and Mary Dalton's boyfriend - a relation that upset Mary's parents.

"Biggers' right hand still gripped the steering wheel and wondered if he ought to shake hands with this white man" (Wright, 1989: 66).

The relationship between Jan and Mary doesn’t get pleased from Mary's parents because Jan was a member of Communist Party.

In the past had they not always drawn the picture for him? He could tell them anything he wanted and what could they do about it? It was his word against Jan's, and Jan was a red (Wright, 1989: 149).

Jan, like Mary, wants to treat Bigger as an equal, but such untraditional behavior only frightens and angers Bigger.

(2) Mr. Dalton

He is Mary's father, a white millionaire who lives in Chicago.

Physically he is white, and tall.

"Grabbing the arms of the chair, he pulled himself up-right and found a tall, lean, white-haired man holding a piece of paper in his hand". (Wright, 1989: 47)

Although he profits from charging high rents to poor black tenants- including Bigger's family - on Chicago's South Side, he nonetheless claims to be a generous philanthropist and supporter of Black Americans.

"I want you to know why I'm hiring you." 
"Yessuh."

"You see, Bigger, I'm a supporter of the National Association for the Advancement of Colored People. Did you ever hear of that organization?" (Wright, 1989: 54-55).

(3) Mrs. Dalton

Mrs. Dalton is blind. "she's blind!" (Wright, 1989: 49). But also a kind person. "But Mrs. Dalton's the one who really nice” (Wright, 1989: 57).

(4) Bessie Mears

She is Bigger's girlfriend. Their relationship remains quiet distant and is largely based upon mutual convenience rather than romantic love.

(5) Mrs. Thomas

She is Bigger's mother. Mrs. Thomas has accepted her precarious, impoverished position in life and wants Bigger at the beginning of the novel that he will meet a bad end if he fails to change his life.

"If you don't stop running with that gang of yours and do tight you'll end up where you never thought you would. You think I don't know that you boys doing, but I do. And the gallows is at the end of the road you travelling, boy. Just remember that." (Wright, 1989: 13)

(6) Buddy Thomas

He is Bigger's young brother. Unlike Bigger, Buddy does not rebel against his low position on the social ladder.

(7) Vera Thomas

She is Bigger's young sister. Like Bigger, Vera lives her life in constant fear.

(8) G.H., Gus, and Jack

They are Bigger's friends, who often plan and execute robberies together.

(9) Mr. Blum

A white man who owns a delicatessen on the South Side of Chicago. Mr. Blum represents and inviting robbery target for Bigger and his friends, but 
their fear of the consequences of robbing a white man initially prevents them from following through on their plan.

"I got haul all figured out," Bigger said.

"What haul?"

"Old Blum's"

There was silence. Jack lit a cigarette. Gus looked away, avoiding the conversation.

"If Old Blum was a black man, you-all would be itching to go. "cause he's white, everybody's scared." (Wright, 1989: 26)

(10) Britten

$\mathrm{He}$ is a racist, anticommunist private investigator who helps Mr. Dalton investigate Mary's disappearance. Physically, he looks like a white military man. "The moment whirling brought him face to face with what seemed to his excited senses an army of white men" (Wright, 1989: 145).

He is a white cold person, and does not seem like Bigger because he is black.

The white man at Mr. Dalton's side was squinting at him; he felt that tight, hot, choking fear returning. The white man clicked on the light, he had a cold, impersonal manner that told Bigger to be on his guard. In the very look of the man's eyes Bigger saw his own personality reflected in narrow, restricted terms. (Wright, 1989: 146).

(11) Buckley

The incumbent State's Attorney whose running for reelection. "I'm the State Attorney, Buckley said (Wright, 1989: 271), "You're afraid that you won't be able to kill this boy before the April elections, if we handle his case, aren't you, Buckley?” Jan asked (Wright, 1989: 271). He is viciously racist and anticommunist, "What in hell you reds can get out of bothering with black thing like that, God only knows, Buckley said (Wright, 1989: 271).

(12) Peggy

She is an Irish immigrant who has worked as the Dalton's cook for years, "I'm Irish, you know," (Wright, 1989: 58). Peggy considers the Daltons to be a kind family, "Mr. Dalton's a fine man," "But Mrs. Dalton's the one who 's really nice.” (Wright, 1989: 57) 
(13) Doc

He is the black owner of a pool hall on the South Side of Chicago that serves as a hangout for Bigger and his friends.

They looked at each other and laughed. They went inside. The poolroom was empty, save for a flat, black man who held a halfsmoked, unlit cigar in his mouth and leaned on the front counter. To the rear burned a single green-shaded bulb.

"Hi, Doc," Bigger said.

"You boys kinda early this morning," Doc said (Wright, 1989: 25)

(14) Reverend Hammond

He is the pastor of Mrs. Thomas's church who urges Bigger to turn toward religion in times of trouble.

\section{Setting}

\section{a. Setting of time}

The situation in the novel Native Son shows that the setting of time is about between 1920 - 1940. It shows from the fact that migration of black from south to the north which is increased rapidly in the 1920s (http:/www.nhc.rtp.nc.us/tserve/nineteen/nkeyinfo/aarcwgm.htm). Like Bigger's confession to Jan that actually he was still five years in Chicago.

"Where were you born, Bigger?"

"In the south."

"... how long have you been in Chicago?"

"Oh about five years." (Wright, 1989: 74).

Richard Wright in his essay "How "Bigger" was Born" tells that Bigger itself is a story from the black condition that he ever met in his life when he was a child. He says, :The birth of Bigger Thomas goes back to my childhood..." and in the 1930s when he wrote this book, he was inspired by the social condition at that time, as he writes that, "In 1932 another source of information was dramatically opened up to me and I saw data of a surprising nature that helped to clarify the personality of Bigger Thomas." (Wright, 1989: Xviii). 
Moreover, Wright is one of the member of Communist Party so Bigger Thomas's story has a connection with the Communist Party which is in the 1928 - 1940 tried to get raised. His novel is used to be his weapon to rise the Communist Party popularity, as John Reily said in his Afterword of the Native Son:

In the 1930s, however Wright believe that the communist party had to means to end oppression ... in is writing right intended to interpret the experience of the Negro underclass to the communists so that the party could them devise programs for their advancement (Reilly in Wright, 1989: 396).

From the citation above it could be concluded that the setting of time in Native Son is about in $1920-1940$.

\section{b. Setting of Place}

The story of the novel of Native Son mostly of them is happened in Black Belt, in the South Side of Chicago. Black Belt is the place for the black community, just like Max considers about it, that white people settled the black community in that area. It is shown when Max interrogate Mr. Dalton in the police department, "You rent houses to Negro in the Black Belt and you refuse to rent tp them elsewhere" (Wright, 1989: 362). Black Belt is a densey place, poor, and bad condition, it tells by someone of the black who caught by the police.

"... You make us live in such crowded condition on the south side that one out of every ten of us is insane!... you dump all the stale food into the Black Belt and sell them for more than you can get anywhere else" (Wright, 1989: 318).

The novel of Native Son also takes place on the jail in Illinois called Cook County Jail. In this place Bigger has been jailed and also receive his death, just when State Attorney told Bigger after the interrogation, "After the inquest they'll take you to the Cook County Jail." (Wright, 1989: 270). 


\section{Plot}

After examining the Native Son, the writer concludes that the plot is progressive plot. The arrangement is as follows:

\section{a. Exposition}

The story starts by introducing Wright's curious and resistible character, Bigger Thomas, which then leads him to lot damages and difficulties he makes in his life. he is a young black man in Chicago, who lives in a one-room apartment in Chicago's South Side Black Belt, with his mother, his young sister Vera, and young brother Buddy. He is hired by a wealthy family named Dalton as their chauffeur. The family's free - thinking daughter Mary befriend with him. With her, he meets Mary's boyfriend Jan Erlone.

"Oh, Bigger, this is Jan. and Jan this is Bigger Thomas." Jan smiled broadly, then extended an open palm toward him (Wright, 1989: 66) "We may as well get to know each other," Jan said. "I'm a friend of Mary's." (Wright, 1989: 67).

\section{b. Complication}

The complication begins when Mary and Jan drink too much, and then get drunk. After carrying Jan to his place then Bigger carries Mary to go home. Mary cannot stand by herself perfectly, so Bigger carries Mary to her room. When they got to Mary's room, Mrs. Dalton enters the room. Bigger accidentally smothers her. In panic, he cover's Mary's face with pillow until she dead. In panic, he burns the body in the basement and attempt to implicate Jan, Mary's bones are discovered.

"He started at the furnace. He trembled with another idea. $\mathrm{He}-$ he could, he - he could put her, he could put her in the furnace. He would burn her! That was the safest thing of the furnace. He went to the furnace and opened the door. A huge red bed coals blazed and quivered with molten fury. (Wright, 1989: 89).

\section{c. Climax}

The story gets its climax when Bigger killed Bessie, his girlfriend to cover his tracks. Bigger cannot make Bessie shut up. She always afraid and worried because Bigger has killed Mary. Bigger is afraid if Bessie tells the truth to the police, that's why he kills Bessie with a brick. 
He could not take her with him and he could not leave her behind. He reconstructed in his mind the details of the room as he had seen them by the glow of the flashlight when he had first come in. the window was directly behind him, above his the flashlight, the handle pointing toward him, so he could get it quickly and e in a position to use it, but he could not use the gun; that would make too much noise. He would have to use a brick. (Wright, 1989: 223).

Then after knowing that Bessie does not breathe, Bigger escapes to safe himself from the police. But he us captured and jailed.

\section{d. Resolution}

When Bigger is captured because of two murderers, he feels the satisfaction. But he also feels that it's his destiny that he must face, “... He felt that he had his destiny in his grasp". (Wright, 1989: 141). All the thing to do has the consequences. Bigger realizes that he has killed two girls, it makes him satisfied but also he must take the responsibility of it, “... The long train of disastrous consequences that had flowed from it", (Wright, 1989: 255). In the jail he starts thinking how his life to be. After judge gives him punishment to the death, he feels lonely. He starts to worry. He only thinks whether his life is worthy or not. It is stated by the author as follows,

He did not eat now; he simply forced food down his throat without testing it, yo keep the gnawing pain of hunger away, to keep from feeling dizzy. And he did not sleep; a intervals he close his eyes for a while, no matter what the hour; then opened them at some later time to resume his brooding. He wanted to be free of everything that stood between his and his end, him and the full and terrible realization that lie was over without meaning, without anything being settled... (Wright, 1989: 382)

Bigger was really thing about his life which is two hours left. He really realized the consequences for what he has done.

\section{Point of View}

By observing the novel, the writer can examine that Native Son is an autobiographical novel, and Bigger Thomas, as the narrator uses the first person point of view. The narrator takes a part in the story. Further, since this novel is an 
autobiographical novel, he places himself as the major character. The other characters in this novel are made to support the development of the story.

\section{Style}

\section{a. Diction}

Wright presents his writing in the naturalistic tradition, in Native Son, Richard expresses the sorrow, the poverty of his life, the humiliation, the discrimination of white's treatments, on the chosen of the language he uses. He uses vigorous and straightforward English. The simple and comprehensive English makes its readers easily understand the meaning and the central idea he wants to perform. He also activates the black's enthusiasm and consciousness to fight for their rights. The use of Negro English that sometimes contains slang and ungrammatical utterances in the dialogue also portrays vividly and clearly the Negroes' lifestyle, uneducated and unintelligent blacks.

"Only God can help you now, boy. You'd better get your soul right!"

"I ain't got no soul;!"

"Take your Jesus and go!"

"But, Son!” Yuh don't know whut yuh's sayin'”!Lemme pray fer yuh!"

"Pray for yourself!" (Wright, 1989: 314).

\section{b. Grammatical Structure}

Richard Wright uses long narrative and description sentences. He often explains something by using details items. Usually its description is the representative of his environment, society in America in the early of the twentieth century.

c. Rhetoric

(1) The figurative language

(a) Figures of thought

The prominent of thought in this novel are simile, and personification. A simile is a language style that compares something with the other. For example, "You laugh like monkeys and you ain't got nerve enough to do nothing but talk." (Wright, 1989: 26). It means that they are really bad in attitude. 
Personification, is figurative language which provides the nature of fixed object with the nature of man properly, until it can attitude and behavior like man. For example, 'A plane was writing high up in the air.' (Wright, 1989: 19). It means that plane is supposed could write like human.

(b) Figures of speech

The prominent of figures of speech in this novel are repetition, anaphora, polysindenton, and asyndenton. Repetition is group of repetition. Example, "Lord, Lord, have mercy..." (Wright, 1989: 10). A repetition can be called anaphora if there are at least two consecutively sentences that used word of word repetiotion in the beginning of sentence. For example, "I reckon I'll be dead then. I reckon God'll call me home. "(Wright, 1989: 13).

Polysindenton is repetition which used 'and' repetition. Example, '... hearing the roll of tom-toms and the screams of black men and woman dancing free and wild, men and women who were adjusted to their soil and at home in their world, secure from fear and hysteria.' (Wright, 1989: 36).

Asyndenton is repetition that uses comma (,) repetition. Example, '... The Gay Women in which, amid scenes of cocktail drinking, dancing, golfing, swimming, and spinning, roulette wheels, ... '(Wright, 1989: 33).

(2) Imagery

Imagery is the use of words and sentences express by author that can raise the sense reaction of the readers called imagery. It has a function to make the readers imagine, feel, and concrete a condition in the story that actually abstract. Example “... You make us live is such crowded condition on the south side that one out of every ten of us insane! ... you dump all the stale food into the Black Belt and sell them for more that you can get anywhere else" (Wright, 1989: 318). This sentence describes the condition of black society in the Black ghetto, Black Belt in order to make the reader imagine it and make it concrete in his mind. 


\section{Theme}

The theme of the Native Son is that "the sense of all human being, of all man in this world is equal before God and before the law". Naturally, all human being are created equal. They have the same feelings and are as alike on the inside as they are different either injustice or discriminated by inhumane treatments, horrible terrors and lynching.

\section{B. Summary}

Richard Wright is an eloquent naturalist writer. He is the first black novelist writer who writes vigorously the works of literature deal with the subject that has been regarded as taboo thing. His works of portraying the oppressed Negroes have made a deep impression on the readers for over the world. He considers that novels are the good public relations, and are as the weapons in his effort of being a literary spokesman for the oppressed Negro minority in the United States. His novel of Native Son is his masterpiece, which becomes a kind of universal history of a vital discrimination in America.

Having observer and analyzed structurally the novel of Native Son. The analysis in this novel comes to a summary. In his novel Native Son, Richard Wright intends to announce to the world, that the reasons, such as: racial differences and color-skin differences shall not irritate or inhuman man's sense as the human being. As the human being, a man naturally deserves to love in a normal and decent way of life, as what God has mapped out. Richard shows to the world that black people, that Negroes also have feeling, hope, loyalty, dream, aspiration, emotion, passion hate and self-respect as whites do.

Wright develops the major character's personality in rebelliousness and introversion manner, who constantly questions for selfhood, a longing for freedom in order to strengthen his theme, searching for freedom.

The provision of the other characters and their characterizations in this novel are arranged to portray clearly the problem that Richard wants to perform. The characterizations, the lifestyle, and the attitudes of the other characters support Richard's aim in writing this novel. 
To make this central idea clear, the narrator uses traditional plot which is easy to comprehend. The story us presented in the suitable chronology, as what Wright has undergone his life experiences, a moving account from his boyhood to young manhood.

The language style in this novel also supports the intended idea and aim of the narrator. As we can see it in the text and the dialogues that he narrator has organizd the text uses the simple, comprehensible, vigorous and straightforward English, in order to make its reader easily comprehend the central idea. The use of the chosen language spoken by both black and whites vividly portrays the social background of this novel.

Finally, the analysis in this chapter concludes that the structural analysis of Richard Wright's Native Son shows that all of the elements of this novel are related to one another. The relation of the theme, characters and characterizations, plot, setting, and style combine to build a unified meaningful work of literature.

\section{REFERENCES}

Freedman, Ronald. Et.all. 1952. Principles of Sociology: A Text With Readings. New York: Henry Holt and Company.

Fuchs, Lawrence. 1994. Kaleidoskop Amerikana. Bandung: PT. Remaja Rosdakarya.

Garis Besar Sejarah AMerika. 2004. Amerika: Badan Penerangan Amerika Serikat.

Handlin, Oscar 1995. Immigration as a Factor in American History. Englewood Clifss, N.J: Prentice-Hall. Inc.

Hargosewoyo, Paul Surono. Drs. 1984. Konflik dan Konsesnsus Dalam Sejarah Amerika Modern. Massachussets, USA: Gajahmada University Press.

Kutha, Ratna Nyoman. 2003. Paradigma Sosiologi Sastra. Yogyakarta: Pustaka Pelajar Offset.

Lukacs, John. 1993. The End of the Twentieth Century and the End of the Modern Age. New York.

Mauk, David and John Oakland. 1997. American Civilization: An Introduction. London and New York: Paladin.

Nurgiyantoro, Burhan. 2000. Teori Pengkajian Fiksi. Yogyakarta: Gadjah mada University Press. 
Rtr-52.2005. “Rasialisme di Penjara AS”. Suara Merdeka. February 23th, 2005.

Wellek, Rene and Austin Warren. 1993. Teori Kesusastraan. Jakarta: PT. Gramedia Pustaka Umum.

Wright, Richard. 1989. Native Son. New York Harper \& Row, Publisher. 